\title{
Analysis of the effectiveness of the systems protecting against the impact of water damming in the river on the increase of groundwater level on the example of the Malczyce dam
}

\author{
Arkadiusz Głogowski ${ }^{1, *}$, and Mieczysław Chalfen $^{2}$ \\ ${ }^{1}$ Institute of Environmental Protection and Development, Wroclaw University of Environmental and Life Sciences, Poland \\ ${ }^{2}$ Department of Mathematics, Wroclaw University of Environmental and Life Sciences, Poland
}

\begin{abstract}
The aim of the article is to determine to what extent individual elements of the project protecting the village of Rzeczyca and adjacent areas against flooding after the planned damming up of water in the Odra on the Malczyce dam. The assessment of the impact of damming on the nearby towns was made using a mathematical model based on a two-dimensional and non-stationary version of the Boussinesq equation and the finite element method (FEM). In the simulations, the proprietary FIZ software was used for calculating water flow and chemical pollution in a porous medium. Four computer simulations were carried out, modelling the flow of groundwater in the left-bank Odra valley. The first simulation was run in pre-towering conditions, the second one included water damming without additional safeguards, the third one with a watertight membrane and the fourth one with a membrane and a drainage channel.
\end{abstract}

\section{Introduction}

Human interference in the natural environment often entails changes that may be irreversible or long-lasting, and their detrimental environmental consequences are difficult to predict. Water barrages have an enormous impact on the environment [1]. Such structures cause not only local changes caused by water damming, but also linear changes along the watercourse due to changes in the water flow velocity, and thus changes in the morphology of stream.

The barrage in Malczyce analysed in the article, located at $300 \mathrm{~km}$ of the Odra river, will be the last regulatory facility on the Odra river after completion of construction [2]. At the same time, coastal areas will be exposed to increased percolation of water from the riverbed. At the left bank of the Odra, next to the constructed barrage, there is the village of Rzeczyca, for which permanent changes in the position of the groundwater table caused by damming up water in the watercourse may mean flooding. In order to protect the area around the village, a protection system against flooding in the form of the percolation protection membrane and two drainage systems was designed: one deep ditch equipped with Zakrzów-Rzeczyca pumping stations and a shallow drainage system draining water to the Jeziorka River [3]. On the right bank of the Odra, there is a plateau for which raising the groundwater level does not entail flooding the area.

\section{Data and Methodology}

The research analysis covers the area located between the rivers Odra in the north, the Średzka Woda and the Jeziorka in the south, which are natural boundaries for the flow of groundwater. For reasons of human safety, special attention was given to urbanized areas (Fig. 1).

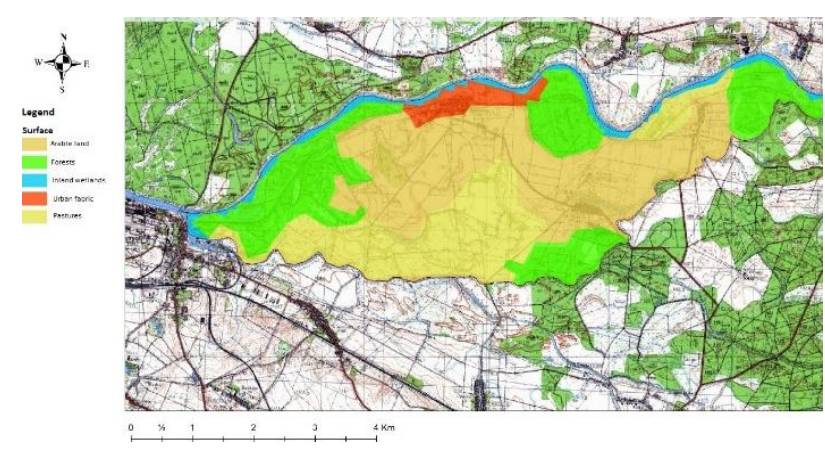

Fig. 1. Map of land cover for the analysed area (source: CLC).

\subsection{Data}

Information on the land cover was taken from the Corine Land Cover. The data of the numerical terrain model was obtained from the Central Geodetic and Cartographic Documentation Centre; the data were afterwards transferred to the finite element grid with 
the use of the method of reverse distances according to the formula:

$$
t_{s r}=\frac{w_{1} t_{1}+w_{2} t_{2}+w_{3} t_{3}}{w_{1}+w_{2}+w_{3}}
$$

where:

$t_{i}$ - the value of the height of the area for three nearest individual points

$\mathrm{w}_{\mathrm{i}}-$ is designated by the formula:

$$
w_{i}=\frac{1}{d_{i}}
$$

where:

$d_{i}$ - the distance of the nearest points from the cloud to the points of the grid.

The geological characteristics were made on the basis of documentation prepared by the HydroGeological Water Engineering Enterprise [4]. The land occurring in the region of Malczyce is divided into three types: Holocene, Pleistocene and Pliocene. On the basis of this division, differences in soil properties were determined (Tab. 1).

Table 1. Values of permeability coefficients for individual types of soil.

\begin{tabular}{|l|c|c|}
\hline \multicolumn{3}{|c|}{ Holocene soil } \\
\hline & permeability coefficient $\left[\mathrm{cm} \cdot \mathrm{s}^{-1}\right]$ \\
\hline & from & to \\
\hline gravel & $4.5 \cdot 10^{-3}$ & $1.4 \cdot 10^{-2}$ \\
\hline aggregate & $4.7 \cdot 10^{-4}$ & $3.0 \cdot 10^{-2}$ \\
\hline coarse sand & $7.7 \cdot 10^{-4}$ & $3.0 \cdot 10^{-2}$ \\
\hline medium sand & $1.0 \cdot 10^{-3}$ & $9.5 \cdot 10^{-2}$ \\
\hline fine sand & $2.2 \cdot 10^{-3}$ & $8.5 \cdot 10^{-3}$ \\
\hline & Pleistocene soil \\
\hline gravel & $1.9 \cdot 10^{-3}$ & $1.2 \cdot 10^{-2}$ \\
\hline aggregate & $1.3 \cdot 10^{-3}$ & $3.7 \cdot 10^{-2}$ \\
\hline coarse sand & $1.1 \cdot 10^{-2}$ & $4.6 \cdot 10^{-2}$ \\
\hline medium sand & $8.5 \cdot 10^{-4}$ & $3.3 \cdot 10^{-2}$ \\
\hline fine sand & $2.5 \cdot 10^{-4}$ & $1.3 \cdot 10^{-2}$ \\
\hline clayey sand & $1.3 \cdot 10^{-6}$ & $7.7 \cdot 10^{-4}$ \\
\hline & Pliocene soil \\
\hline loam & $1.3 \cdot 10^{-8}$ & $1.3 \cdot 10^{-3}$ \\
\hline
\end{tabular}

The identification of parameters used in simulations of the mathematical model was carried out using measurements of groundwater level in piezometers carried out in the years 1970-2010 [2].

\subsection{Methods}

Multivariate calculations use a time-dynamic, twodimensional, horizontal model of water flow in the saturation zone [5]. The basis of the model is formed by the Boussinesq equation resulting from Darcy's and law of preservation $[6,7]$ :

$$
\mu \frac{\partial h}{\partial t}=\frac{\partial}{\partial x}\left(T \frac{\partial h}{\partial x}\right)+\frac{\partial}{\partial y}\left(T \frac{\partial h}{\partial y}\right)+w
$$

where:

$x, y$-spatial coordinates [m],

$t$ - time [d],

$h(x, y, t)$ - piezometric head $h[\mathrm{~m}]$ at the point with the coordinates $x, y$ at the moment $t$, depends on the type of percolation:

- free percolation: storage coefficient [-]

- pressure percolation: storage capacity [-]

$T$ - permeability - depends on percolation character $\left[\mathrm{m}^{2} \cdot \mathrm{d}^{-1}\right]$ :

- free percolation: $T=k \cdot(h-a)$,

- $\quad$ pressure percolation: $T=k \cdot m$,

$k$ - permeability coefficient $\left[\mathrm{m} \cdot \mathrm{d}^{-1}\right]$,

$a$ - aquifer bottom [m],

$m-$ aquifer thickness [m],

$w$ - source function $\left[\mathrm{m} \cdot \mathrm{d}^{-1}\right]$.

The equation (3) was supplemented with an initial condition reflecting the state of groundwater at the initial moment of simulation. The boundary-limiting paths, with states depending on the calculation variant, define the head boundary condition.

The Boussinesq equation together with the initial condition and accepted boundary conditions was solved by the finite element method $[8,9]$. The grid of triangular elements consists of 6728 nodes and 12975 elements. Its fragments are shown in Figures 3 and 4 . The average side of the triangle was $58 \mathrm{~m}$. The average maximum angle of the triangle was $64^{\circ}$, which means that the triangles are very close to equilateral triangles, which in turn has a positive effect on the accuracy of calculations. The discretization of the filtration area was carried out by means of an irregular grid of triangles, generated automatically and concentrated in regions of the expected larger flow gradients. The scale of the modelled object allows to reduce the mesh size in the most sensitive areas, that is in the vicinity of the channel of less than $20 \mathrm{~m}$, and thus increase the accuracy of numerical solutions. The computer program FIZ [10], designed for dynamic modelling of water flow (as well as chemical pollution) in two-dimensional flat sections in plan or vertical, was used in the calculations.

\subsection{Identification and verification of the model}

In computer simulations using models with distributed parameters, it is often difficult to empirically determine parameters by identification. In the model used here, this parameter was variable. The permeability coefficient, which in the subsequent calculations was changed so that the calculated ordinates of the groundwater table would agree with the values measured in a series of piezometers. After identifying the permeability coefficient, the model was verified by 




Fig. 2. Distribution of hydroizohypses with exemplary trajectories of groundwater flow. Red line - watershed water.

comparing the calculated ordinates of the water table with measurements from the years 1970-2011 [11]. As the boundary conditions, medium-sized water levels in the Odra, the Średzka Woda and the Jeziorka were assumed before the planned damming [2]. The water level in the Odra River at the entrance to the model amounted to $98.32 \mathrm{~m}$ asl. on the outflow at the Malczyce water gauge $94.77 \mathrm{~m}$ asl. The condition of water in the Jeziorka and the Średzka Woda.

The average annual daily supply of the saturation zone from the aeration zone in the amount of $w=0.0003$ $\mathrm{m} \cdot \mathrm{d}^{-1}$ was taken into account $[12,13]$.

The calculated hydroizohypses and trajectories of water flow are shown in Fig. 2. The Odra along the entire length is a draining river. In the eastern part of the watercourse, the Jeziorka recharges groundwater in the valley, and in the southern part, the river drains it. The horizontal line of groundwater is marked in red. The picture is fully in line with what you see in reality. Among the eight selected piezometers in the studied area [2], four fall within the range between the limit values of the groundwater table. The ordinate of water calculated in the G4 piezometer is $20 \mathrm{~cm}$ lower than the minimum measured in reality (tab. 2). The average absolute error was $0.43 \mathrm{~m}$, which was considered correct for further analysis.

Table 2. A comparison of the minimum, maximum and average states of selected piezometers with the calculated state of groundwater.

\begin{tabular}{|c|c|c|c|c|}
\hline Piezometers & $\begin{array}{c}\text { Minimal } \\
\text { level of } \\
\text { GW }\end{array}$ & $\begin{array}{c}\text { Maximal } \\
\text { level of } \\
\text { GW }\end{array}$ & $\begin{array}{c}\text { Mean } \\
\text { level of } \\
\text { GW }\end{array}$ & $\begin{array}{c}\text { Calculated } \\
\text { level of } \\
\text { GW }\end{array}$ \\
\hline PL9 & 98.28 & 100.15 & 99.52 & 99.60 \\
\hline PL12 & 99.07 & 99.59 & 99.32 & 99.34 \\
\hline PL13 & 97.48 & 100.73 & 99.42 & 99.60 \\
\hline H2a & 98.21 & 99.67 & 98.69 & 97.77 \\
\hline H2b & 98.49 & 99.18 & 98.86 & 97.86 \\
\hline H1a & 97.82 & 99.04 & 98.09 & 97.45 \\
\hline L4a & 96.83 & 97.56 & 97.04 & 97.01 \\
\hline G4 & 98.38 & 98.80 & 98.62 & 98.18 \\
\hline
\end{tabular}

\section{Simulations}

The developed model was used to study the impact of various protective systems against flooding of leftbank areas after the planned damming up of the Odra River. Above the degree, the boundary condition was introduced in a manner corresponding to the water damming in the Odra to the planned elevation of $101.40 \mathrm{~m}$ above sea level. Above the barrage level, the water level in the Odra River was assumed from 101.42 to $101.40 \mathrm{~m}$ above sea level. Below the barrage, the boundary condition was assumed as before the damming up. On the Jeziorka and the Średzka Woda, it was assumed that after damming the water in the Odra, the water levels in these watercourses will not change.

\subsection{Ground water conditions after damming}

First, simulations were carried out in which no safeguards were applied. Such an approach allowed to determine the impact that the water level will exert on the left-bank coastal areas of the Odra and allowed us to further assess the effectiveness of other protections provided for in the project against the negative impact of damming.

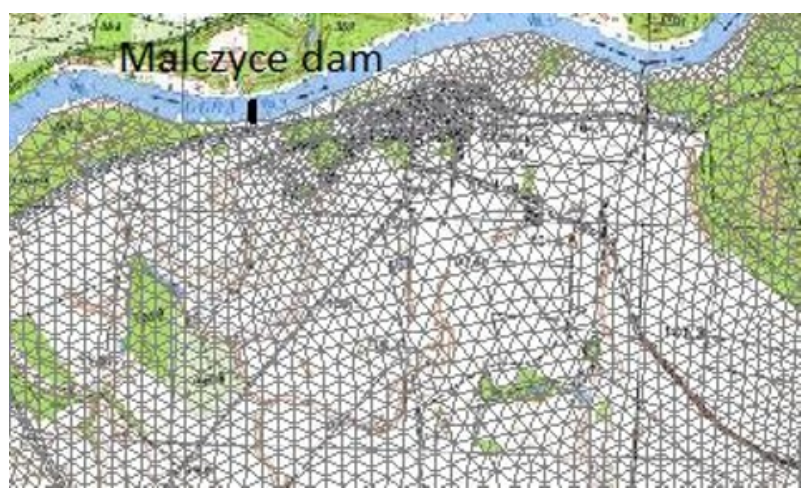

Fig. 3. Localization of Malczyce barrage. 


\subsection{Ground water conditions after damming the river with watertight membrane}

The variant with the use of a percolation protection membrane to the aquifer bottom allows for determining whether and to what extent the designed membrane protects the city against the impact of damming. The watertight diaphragm was defined by means of the permeability coefficients, giving it a value of $\mathrm{k}=0 \mathrm{~m} \cdot \mathrm{d}^{-1}$ for the cross section in which the diaphragm is to be mounted (Fig. 3). The length of the diaphragm completely separates the village of Rzeczyca from the Odra. The membrane located along the flood embankment has the length of $1250 \mathrm{~m}$. In the model, the membrane is shown schematically. Despite the differences in the shape, the impermeable layer of the model meets the safety function planned in the project.

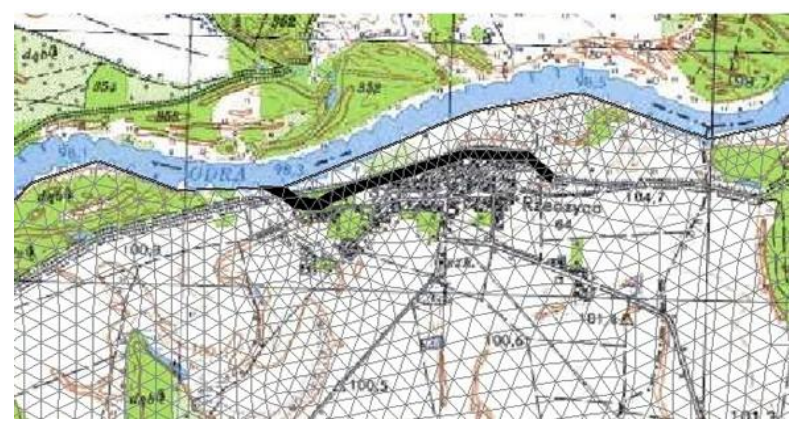

Fig. 4. Membrane protecting the village Rzeczyca.

\subsection{Ground water conditions after damming the river with watertight membrane and drainage system}

The last simulation maps the full design of the protection of the river's left bank. An additional boundary condition was introduced to the model, which is the equivalent of the designed "Zakrzów" drainage channel (Fig. 5), with a length of $6.3 \mathrm{~km}$. It is defined by the head boundary condition with the ditch filling $0.30 \mathrm{~m}$ assumed in the project. A water drop in the channel from 99.40 to $96.11 \mathrm{~m}$ asl. is assumed. The model takes into account the operation of the channel only if there is groundwater above the bottom of the drainage channel.

\section{Results}

In the first calculation variant, after damming without any protection, groundwater in the direct location of the Odra River above the damming level rose even by $4.50 \mathrm{~m}$. The range of changes covers about $90 \%$ of the area towards the south and east, upstream (Fig. 6). The Odra above the damming stage feeds the valley. Below the Malczyce dam it retains its drainage properties. Groundwater stagnancy could cause total unserviceability of arable land for further cultivation.

Changing ground conditions could also bring about loss of stability of many houses and farm buildings. Water in the immediate vicinity of the Odra riverbed floods adjacent areas. After employing a membrane, groundwater level in the area of the town decreased by $2 \mathrm{~m}$ (Fig. 7). However, the area remains within the city limits, where groundwater would fall from $2 \mathrm{~m}$ to $1.5 \mathrm{~m}$. As a result basements would be flooded. This is not the final solution because the project already has an existing drainage channel "Zakrzów". It reduces the range of changes determined by different hydroizohips with a value of $0.5 \mathrm{~m}$ to just $500 \mathrm{~m}$ south of the drainage channel "Zakrzów" (Fig. 8). Changes in further parts of the area are small and can be omitted when considering the negative effects of damming up water. The direction of groundwater flow has been limited and is comparable to the conditions before the damming-up. The Odra after damming up water to an ordinate of $101.40 \mathrm{~m}$ above sea level, remains a watercourse supplying the valley; on the other hand, the "Zakrzów" channel acts as a buffer, receiving water coming from the Odra river due to water damming up. The designed protection in this calculation variant effectively protects the left-bank areas of the Odra river. A watertight membrane protects the town from the impact caused by water damming. The "Zakrzów" channel efficiently drains excess water supplied from the Odra river. The accumulation of water affects the distribution of water discharged by the Odra and the Jeziorek rivers. The amount of water leaving the analyzed area decreased due to the smaller water flow rate due to the increase in the water level.by piling water on the Malczyce step above the structure, the Odra is changed from the draining river to a river feeding the valley. Prior to damming, the Odra was the

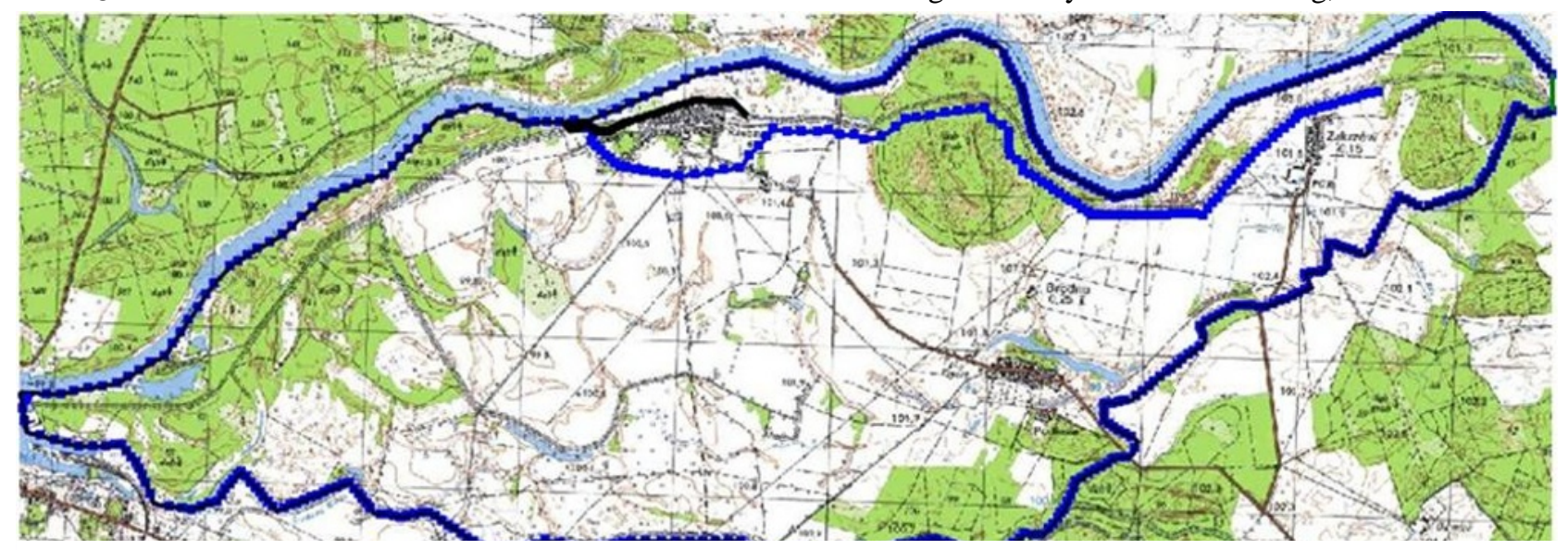

Fig. 5. Dirichlet conditions: light blue colour - "Zakrzów" channel, dark blue - the Odra, the Jeziorka and the Średzka Woda. 




Fig. 6. Difference in water level before and after damming for pre-set conditions.

main drainage channel in the analysed area. It discharged about $61 \%$ of groundwater from the area. According to the calculations, after the damming-up, the Odra would take water only below the Malczyce stage, and the amount of drained water would drop to $24 \%$.

The Jeziorka river will be the main draining river $64 \%$ of discharged waters. The Zakrzów canal would discharge about $12 \%$ of water (Tab.3).

Table 3. Distribution of groundwater run-off before and after damming with the use of designed collaterals.

\begin{tabular}{|c|c|c|}
\hline \multirow{2}{*}{ Before } & Outflow & $\%$ \\
\cline { 2 - 3 } & {$\left[\mathrm{m}^{3} \cdot \mathrm{d}^{-1}\right]$} & {$[-]$} \\
\hline Jeziorka & 3776.3 & 38.7 \\
\hline Zakrzów & - & - \\
\hline Odra & 5960.9 & 61.3 \\
\hline Sum & 9737.1 & 100 \\
\hline After & Outflow & $\%$ \\
\hline Jeziorka & 2864.8 & {$[-]$} \\
\hline Zakrzów & 535.1 & 64 \\
\hline Odra & 1076.6 & 24 \\
\hline Sum & 4476.5 & 100 \\
\hline
\end{tabular}

\section{Conclusions}

The four calculation variants allowed for reliable assessment of the impact of each element in the Malczyce water barrage design. The calculated groundwater levels using the FIZ computer software reflect the actual groundwater levels. Water damming to $101.40 \mathrm{~m}$ above sea level changes the character of the Odra river from a river draining the valley to a river Without protection, groundwater after damming-up through the Malczyce step increases by as much as $4.50 \mathrm{~m}$ compared to the current state. The largest increments can be expected in the immediate vicinity of the Odra riverbed.



Fig. 7. Difference of groundwater table between damming without protection and damming with a filtration protection membrane for pre-set condition.

The range of damming groundwater by at least $1 \mathrm{~m}$ is at a distance of $500 \mathrm{~m}$ to $1500 \mathrm{~m}$ from the Odra. A membrane effectively protects the village of Rzeczyca from flooding. Drops of the water table reach up to $2 \mathrm{~m}$ without taking into account the "Zakrzów" drainage channel. The "Zakrzów" drainage channel effectively limits the increase of groundwater level both in the immediate vicinity of the channel and in the further southern part of the valley. The damming range determined by the differences between the actual conditions determined by the $0.5 \mathrm{~m}$ isoline reaches only approx. $500 \mathrm{~m}$ along the Odra channel. In the further parts of the analyzed area, the impact is negligible. After damming water, the amount of groundwater flowing out will decrease by half as a result of raising the water level in the Odra river. The Jeziorka will drain about $64 \%$ of groundwater, thus becoming the dominant drainage channel. The Zakrzów canal will discharge about $12 \%$ of groundwater. Groundwater in the town is not a threat and is located at least $2.5 \mathrm{~m}$ below the ground level (Fig. 9). The mathematical model referred to in the planar system is an effective tool for the analysis of the impact of water damming in the watercourse on the increase in the location of groundwater in the adjacent areas. 


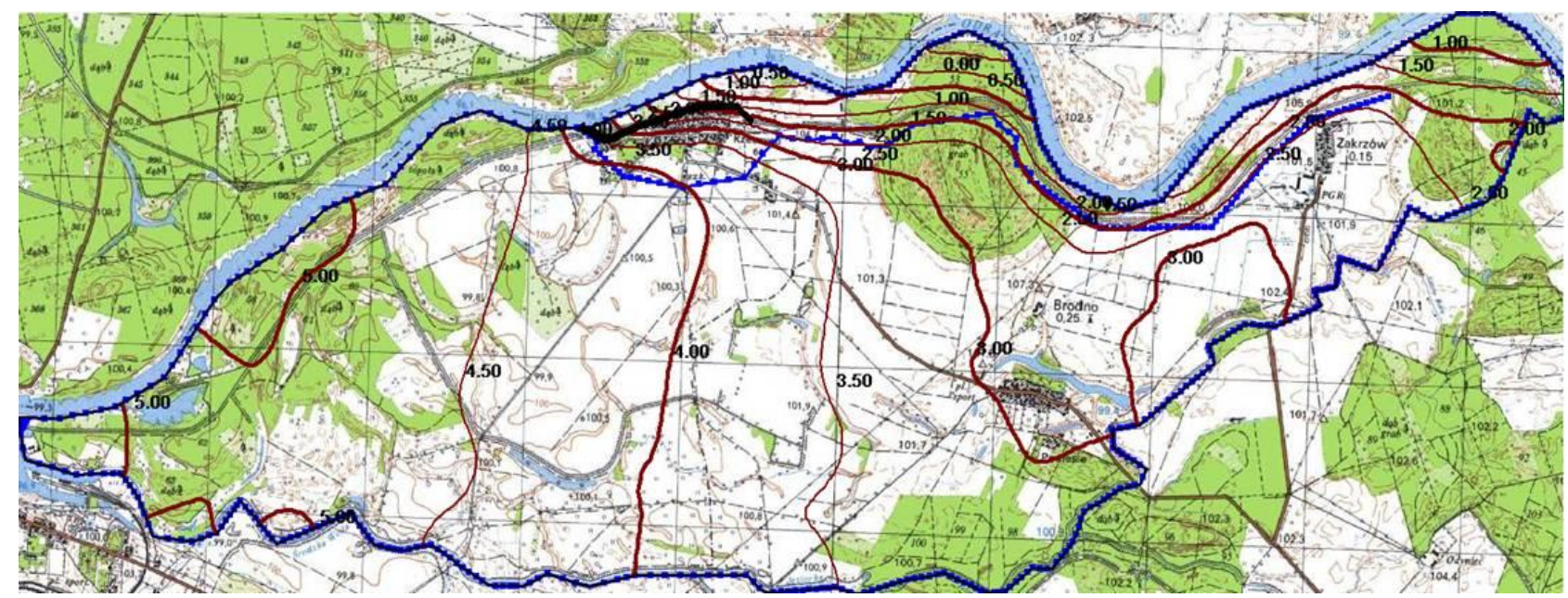

Fig. 8. Differences in the amount of groundwater before damming the Odra River and after accumulation with the use of designed protections.

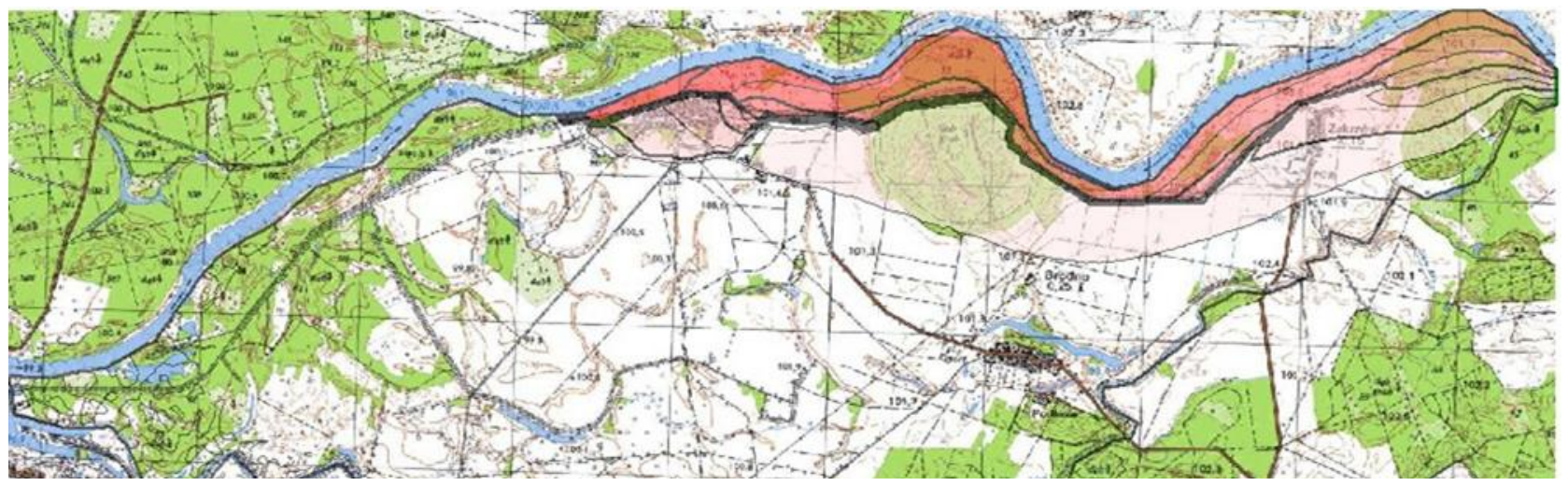

Fig. 9. Isobaths distribution after the Odra damming up with the use of designed protections.

\section{References}

1. M. Chalfen, B. Głuchowska, L. Pływaczyk, Studia Geotechnica et Mechanica vol. 35, no 2/2012, 3-17 (2012)

2. M. Chalfen, W. Łyczko, L. Pływaczyk, Journal of Water and Land Development 21 (1), 19-27 (2014)

3. J. Bielecka, Woda-Środowisko-Obszary Wiejskie T. 5, Z. 1 (13), 23-40 (2005)

4. Hydrogeo, Geological-engineering documentation of the initial data phase (in Polish) (Manuscript, Warszawa, 1968)

5. B. Wosiewicz, Z. Sroka, Z. Walczak, Gospodarka Wodna 2, 58-63 (2005)

6. J. Bear, Flow in Porous Media (Dover, Mineola, N.Y., 1969)

7. W. Kinzelbach, Groundwater modelling (Elsevier, 1986)
8. Z. Sroka, Z. Walczak, B. Wosiewicz, Analiza ustalonych przepływów wód gruntowych metoda elementów skończonych (Wyd. Akademii Rolniczej w Poznaniu, Poznań, 2004)

9. O.C. Zienkiewicz, R.L. Taylor, P. Nithiarasu, Finite element methods for fluid dynamics (Elsevier, 2005)

10. M. Chalfen, 33. Seminarium Zastosowań Matematyki Kobyla Góra (Wydaw. Katedra Matematyki AR, Wrocław, 37-40, 2003)

11. AR Wroc., Studies on the effect of damming the Oder River by Malczyce barrage on water

relations in adjacent areas (in Polish) (Manuscript, Wrocław, 1970-2011)

12. S. Bac, C. Koźmiński, M. Rojek, Agrometeorology (Wydaw. Nauk. PWN, Warszawa, 1993)

13. L. Pływaczyk, Zeszyty Naukowe AR Wrocław 311 (47) (1997) 